\title{
Answer the question: What is Enlightenment?
}

Beantwortung der Frage: Was ist Aufklärung?

(Königsberg in Prussia, 30 September 1784)

By

\section{Immanuel Kant}

(Born in 1724 and died in 1804)

Translation into English by Daniel Fidel Ferrer (2013)

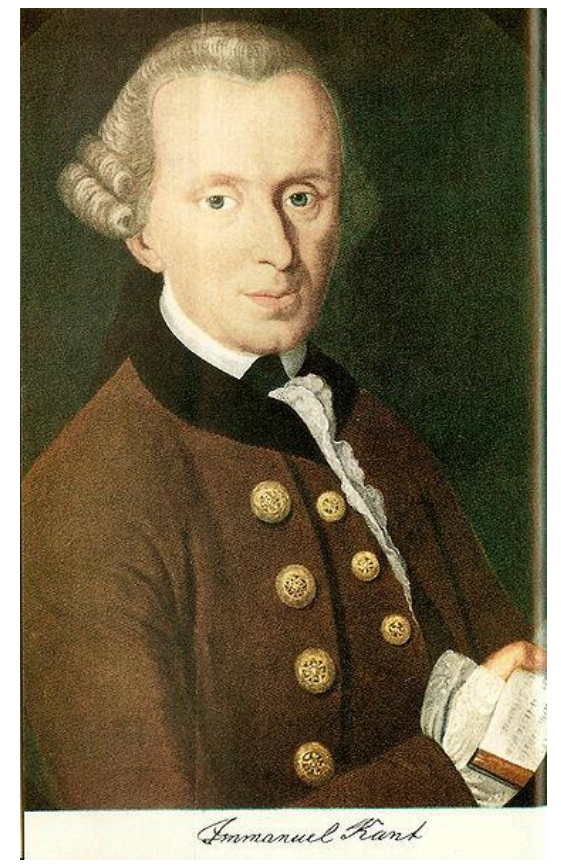




\section{Table of Contents}

Immanuel Kant's Text translated into English (pages 2 to 10).

Notes, Bibliography, Related Links, Etc., Appendix A (pages 12 to 25).

Word Index (pages 26 to 44).

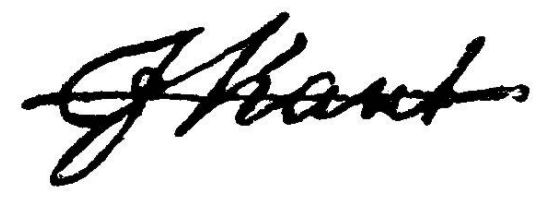

[Start of Immanuel Kant's Text]:

Enlightenment is man's emergence from his self-imposed immaturity (selbstverschuldeten Unmündigkeit). Immaturity is the inability to use one understanding without guidance from another. Self-incurred is this tutelage when its cause lies not in lack of understanding (Versandes), but rather of resolve and courage to use it without direction from another. Sapere Aude! [Latin translated: Dare to know, from Horace]. Have courage to use your own mind! Thus is the motto of Enlightenment.

Laziness and cowardice are the causes (Ursachen), why such a large part of humanity, after nature has released them from external guidance (natura liter maiorennes) [Latin translated: come of age via nature], remain; but like life immaturity, and why it is so easy to set themselves up as their guardians. It is so convenient to be immature. I have a book, which understands for me, a pastor who has conscience (Gewissen) for me, and a physician who decides my diet, etc., so I do not even need to try. I do not think, if only I can pay: others will readily undertake the irksome work for me. That by far the largest proportion of people (including the entire (ganze) fair sex), the step to maturity, but this is that it difficult, even for 
very dangerous to think, have rendered those guardians, the ultimate supervisor (Oberaufsicht) of them graciously took upon themselves. Once they have made their domestic cattle first stupid and have made sure that were these placid creatures will not dare step without the harness is it a like a children's walking cart (Gängelwagen, footnote \#1), if they try it go alone it shows them the danger to them threatens. Now this danger is not so great, for they would learn to walk by falling a few steps times, but an example of this kind makes men timid and usually frightens them out of all further attempts.

So it is difficult for any single individual to work himself out of immaturity as has become almost his own nature. He has even grown fond and forehand is really incapable of his own use of his understanding (Verstandes), because you never let him make the attempt. Statutes and formulas, those mechanical tools of the rational use, or rather misuse, of his natural gifts, are the fetters of an everlasting immaturity (Unmündigkeit). Whoever throws them off would still do well on the narrowest trench only an uncertain leap, because he is not accustomed to kind of free movement. Therefore, there are few who have succeeded in extricate themselves by their own exercise of mind (Geistes) from immaturity and still a steady pace.

But that the public should enlighten itself is more possible, yes, it is; if one is only allowed freedom, Enlightenment is almost sure. For there will always be some independent thinkers (Selbstdenkende), found even among the established guardians of the great masses, who, after throwing off the yoke of immaturity themselves thrown to think the spirit of a reasonable estimate of their own worth and every man's vocation, will spread even to themselves. Especially is herein: that the public, which previously brought by them under this yoke by them afterwards even, forces them to remain among them, when some of his guardians (Vormünder), who are altogether incapable of Enlightenment been incited to do so. Thus, harmful it is, to plant prejudices; for they finally take revenge on those themselves, or their predecessors have been their authors. Thus, a public can only slowly attain 
Enlightenment. A revolution is perhaps probably a waste of personal despotism or of avaricious or tyrannical oppression (herrschsüchtiger Bedrückung); but never a true reform in ways of thinking can come about; but rather, are new prejudices, just as well serve as the old ones to harness the great unthinking mass (gedankenlosen großen Haufens).

For this Enlightenment nothing is required but freedom, namely the most harmless amongst all what may be called freedom, namely: to make use of one's reason (Vernunft) in all public use. But I hear calling from all sides: do not argue! The officer says: do not argue but rather drill! The tax collector: do not argue, but rather pay! The clergyman: do not argue, but rather believe! (Only one ruler in the world says: argue all you want and what you want, but obey (gehorcht)). Here is everywhere restriction (Einschränkung) of freedom. But which restriction hinders Enlightenment and which not, but instead actually advances it? - I answer: the public use of reason must always be free, and it alone can bring about Enlightenment among men; the private use (Privatgebrauch) of reason may often be very narrowly restricted without particularly hindering the progress of Enlightenment. But I understand the public use (öffentlichen Gebrauche) of one's reason, to anyone as a scholar makes of reason before the entire literate world. Private use I call that which he entrusted to him in a certain civil post or office shall make use of his reason. Is now to some businesses (Geschäfte) that run in the interest of the community, a certain mechanism is necessary, by means of which some members of the community must passively conduct themselves in order, by an artificial unanimity, the government for public purposes or the destruction of at least held to these purposes. It is certainly not allowed to see reason alternative, but rather one must obey. If, however, this part of the machine [Translator note: German word is 'Maschine'] at the same time as a member of a whole community, regards itself at the world civil society, and thus in the quality of a scholar who can addresses an audience at the proper sense of expediency alternate, however, without prejudice to the businesses suffering to which he is in part responsible as a passive member. So it 
would be very disastrous if an officer, who is commanded by his superior, was serving on the desirability or utility of a given to command -- he must obey. He cannot be justly constrained from making a scholar of the error in the military service notes and submit them to the public for their opinion. The citizen cannot refuse to pay the taxes imposed on them, indeed, impertinent criticism of such levies, if they are to be paid by them, as a scandal (occasion general insubordination) could be punished. However, the same person does not act contrary notwithstanding this the duty of a citizen, when he publicly expresses his thoughts as a scholar resists the impropriety or even injustice of such tenders. Similarly, a clergyman is connected to do his catechism students and his community after the Church he serves his presentation symbol [Translator note: the German word is indeed: Symbol], for he has been accepting to this condition. But as a scholar he has complete freedom, indeed even the calling to all his carefully tested and well-intentioned thoughts on the faulty in that symbol and suggestions for the better establishment of religion and Church being communicated to the audience. There is devised nothing that could be put to burden his conscience. For what he teaches as a result of his duties (seines Amts, 'his office') as business of the Church, which he presents as something, in respect of which he has not free of violence to teach as he sees fit; but rather that he is hired to carry forward provision for and in the name of another. He will say: our Church teaches this or that and these are the arguments, which he uses. He thus extracts all practical uses for his congregation from precepts to which he would not himself subscribe with complete conviction; but whose presentation he can nonetheless undertake, since it is not entirely impossible that truth lies hidden; but in any event, at least nothing of the inner religion contradictory fact is encountered. Because he believed he had found them, he would not administer his office with a conscience, and he would have to resign. The use, therefore, to an appointed teacher makes of his reason before his congregation is merely private, because this is only one home, however large meeting, and in respect of which he is a priest not free and should it not also be such because he is someone else. In contrast, as a scholar, who through his 
writings to his public; says the world, the clergyman in the public use of his reason enjoys an unlimited freedom to use his own reason and to speak in his own person. If the fact that the guardians of the people (in spiritual matters) should themselves be immature is an absurdity, which amounts to the perpetuation of absurdities (Denn daß die Vormünder des Volks (in geistlichen Dingen) selbst wieder unmündig sein sollen, ist eine Ungereimtheit, die auf Verewigung der Ungereimtheiten hinausläuft).

But should not be a society of pastors, perhaps a Church assembly or a venerable classis (as they call themselves among the Dutch), authorized to commit itself by oath to a certain unalterable symbol in order to secure a constant guardianship over each of its members and by means they lead over the people and to perpetuate this at all? I say this is altogether impossible. Such a contract (Kontrakt), whose intention is to shut off forever all further Enlightenment of the human race would be closed, is absolutely null and void and even if it should be confirmed by the supreme power, by parliaments, and the most solemn peace treaties. One age (Zeitalter) cannot bind itself and to conspire (verschwören), to put the following in a condition that it must be impossible for it to extent it (mainly so earnestly (angelegentliche)) knowledge of errors and clean all continuous writing (weiterzuschreiten) in the Enlightenment. That would be a crime against human nature, whose original determination (Bestimmung) lies precisely in such progress, and the offspring would be fully justified in rejecting those agreements as unauthorized and take malicious manner to discard. Whether the people could themselves have imposed such a law: the touchstone of all that can be adopted as law by a people lies in the question? Now this would have to speak with the expectation of a better specific short period possible to introduce some order: one might let every citizen, and especially the clergy, freely and publicly in the quality of a scholar, that is, make through his writings, on the erroneous of the present institution's remarks. However, the newly introduced order might last until insight into the nature of these matters had so far and tried, that by uniting their voices (though not all) of a proposal 
could bring the throne to take those congregations under protection which had united after their terms of better access to a changed religious organization, but without interfering with those who wanted to leave it at the same. But a persistent, some from anyone publicly doubting religion constitution even within the lifetime of a human, and thus destroy a period in the progress of mankind toward improvement, and is fruitless. But this probably disadvantage even to make the progeny (Nachkommenschaft) is absolutely unauthorized. A man may for his person, and even then only for some time in what is for him to know, postpone Enlightenment; but to do it to renounce it for himself, but even more for posterity, is the sacred violate human rights and get trampled underfoot (Füßen). But what may not decree a people by themselves may still less by a monarch; the people, for their legal authority rests on the fact that it unites the entire people's will (Volkswillen) in their own. If he only sees to it that all the real or perceived improvement there with the civil order: he may demonstrate to subjects's salvation sake by the way can only make themselves necessary what they are doing. This does not concern him, but rather to prevent, lest any other violent is prevented, in the provision and delivery the same to work his fortune after all. He does even his majesty crash when he mixes in this, since the writings, which seek to bring his subjects their insights into the pure, evaluate his own governance, he does this on his own highest insight, where he lays upon himself the reproach: Caesar non est supra Grammaticos [Latin translated: Caesar is not above the grammarians], as well. It is still more when his supreme authority as far humbled, to support the spiritual despotism of some tyrants in his state over his other subjects.

When we are asked now: are we now living into an enlightened age? Then answer is: No (Nein), but in an age of Enlightenment. That the people, as matters now stand, in the whole (Ganzen), would have been able to or could be reduced only in religious matters are using their own understanding without direction from another secure and good to use, it is still missing a lot. The very fact that now being opened for the field to deal with these things and that the obstacles (Hindernisse) to general 
Enlightenment or the release from their self-imposed immaturity is gradually less, of which we have clear indications. In this regard, this age is the age of Enlightenment or the century of Frederick (In diesem Betracht ist dieses Zeitalter das Zeitalter der Aufklärung, oder das Jahrhundert Friederichs).

A prince (Ein Fürst), who finds it not unworthy, that he considered it a duty in matters of religion prescribe nothing to men; but rather to allow complete freedom while renouncing the haughty name of tolerance, is himself enlightened and deserves to be praised by a grateful world and posterity as the first to the sexual immaturity of the human race, proposed (entschlug) at least part of the government, and each was free to operate in all matters of conscience to his own reason. Under him venerable clergy (Geistliche) are allowed, regardless of their official duties, they from the accepted symbol here or there different judgments and insights into the quality of the scholars freely and publicly explain the world for testing; but much more than any other, which is restricted by no official duties (Amtspflich). This spirit of freedom spreads beyond this land, even where external obstacles to a misunderstanding their own government is struggling; because this is illuminated by the example that was at liberty to procure for the public peace (öffentliche Ruhe) and not in the least the unity of the community (gemeinen Wesens). People gradually work their way little by little from rudness (Roheit) of their own accord if only one does not deliberately to keep them in it. (Die Menschen arbeiten sich von selbst nach und nach aus der Roheit heraus, wenn man nur nicht absichtlich künstelt, um sie darin zu erhalten).

I have the main point (Hauptpunkt) of Enlightenment, that is [d.i.], the escape of men from their self-imposed immaturity, especially set in matters of religion: because in respect to the arts and sciences, our rulers (Beherrscher) have no interest in playing guardian over their subjects, moreover, even those immaturity, as is the most harmful, so even the most degrading of all. But the thinking of a head of state who favors religious Enlightenment goes even further and sees: that even in regard to its 
legislation, there is no danger of allowing his subjects to exercise their own public reason use and their thoughts concerning better formulations of the same even with a frank criticism of the already given, before the public world, of which we have a shining example wherein no monarch surpasses the one whom we venerate [Translator note: or, 'worship', or, 'adore'; the German word is 'verehren'].

But only one who is himself enlightened, is not afraid of shadows, at the same time, however, has a well-disciplined and numerous army to guarantee public peace, can say what no free state (Freistaat) may dare, namely: argue all you want, and about what you want; but obey! It appears here is a strange, unexpected transition in human affairs, as well as elsewhere, when you look at it in the large, in which almost everything is paradoxical. A greater degree of civil freedom seems advantageous to a people freedom of thought and yet it places inescapable limitations, a lesser degree of contrast gives this room, all fully to expand its capacity. If, however, that is the hillside and work for free thinking is unwrapped, the nature of this hard shell, the germ, for which it makes most fondly: so does this return gradually to the temperament (Sinnesart) of the people (which this act of freedom gradually is enabled). Finally even to the principles of a government [Translator note: or regime (Regierung)], which itself is would provide conducive to them, the man who is now more machine than as to treat their dignity. *) [Kant's uses the $=$ “*)” as his a symbol for his only footnote].

Königsberg in Prussia, 30 September. 1784.

\section{Kant}

*) I read just today, the weekly news of Büsching's wöchentliche Nachrichten of 13 September, that in 30 September in the Monthly Berlinischen, in which the Herrn Mendelssohn has answered the just stated the same question. To me his answer has not yet come to hand, otherwise I would have held back the current essay, because which may now be only for testing how far the chance's path could bring unanimity of our thought. 
[(*) In den Büsching'schen wöchentlichen Nachrichten vom 13. Sept. lese ich heute den 30sten eben dess. die Anzeige der Berlinischen Monatsschrift von diesem Monat, worin des Herrn Mendelssohn Beantwortung eben derselben Frage angeführt wird. Mir ist sie noch nicht zu Händen gekommen; sonst würde sie die gegenwärtige zurückgehalten haben, die jetzt nur zum Versuche da stehen mag, wiefern der Zufall Einstimmigkeit der Gedanken zuwege bringen könne.]. This is Kant's only footnote in his text.

END of Immanuel Kant's TEXT.

[Last page, citation: Immanuel Kant AA. VIII. AK 8:42].

Translation copyright (C2013 Daniel Fidel Ferrer.

All rights reserved. Free unlimited distribution.

Creative Commons General Public License "Attribution, Non-Commercial", version 3.0 (CPL BY-NC).

Translator's remarks. My translation is closer word for word of Immanuel Kant's actual written text than most of the other translations; therefore, I did not re-write or revise or change Kant's text to help the reader better understand Kant. This translation is 'green' and not over ripe, or in other words: not excessively rewritten. I have generally followed Kant's punctuation and paragraphs as well. I have broken up some long sentences. All translations are some kind of an interpretation - even mine. Indeed, Kant's German is not easy. This text is over 228 years old. Caveats are many: I am not a native speaker of German, I do not know conversational German, I do not teach the German language, I am not a philologist, and I am not a professional translator. Martin Luther who did the famous translation of the Bible into German wrote in a letter, "If anyone does not like my translation, they can ignore it... (September 15, 1530)". I did this translation to learn some of Immanuel Kant's German and appreciate the feel of Kant's text. Of course, I recommend learning German and reading Kant's German text. 


\section{Dedication and Acknowledgements.}

To my many conversations with Harvey Williams about Immanuel Kant. A lunch and an afternoon walk with Professor Dr. Lewis White Beck. Recently, my e-mails about Immanuel Kant's philosophy with Professor Dr. A. K. Rai of Banaras Hindu University's Philosophy Department (where I went to graduate school). I would also like to acknowledge the general philosophical encouragement of Professor Dr. Dr. Holger Zaborowski. My longtime friend and philosophical questioner: Richard Pulaski, including our recent conversations on the overall purpose of Kant's philosophical project. I alone have done this translation. All the errors our mine alone.

Dedication to family members. Julius Kuhn (born in the city of Verden an der Aller, Germany in 1847; he died in 1890 in the city of Grand Rapids, Michigan, U.S.A.). His mother: Catharina Justine Louise Kuhn (born Vogelsang) (1820-1897). Ernesto B. Ferrer, Louise (born Reavis) Ferrer, Joseph R. Ferrer, Alice Amanda Ferrer, Dolores Juanita Ferrer, Shobha Ferrer, Vandana Kiran Young, Scott Young; Kaiden Curtis Young, Maliha Kiran Young, and of course Zoe Ashlynn Young. Ashmita Rita (Marguerita) Ferrer, Marguerita Ruth Ferrer, Ernesto Jo Ferrer, Laurie and Daniel Large. Rafael Ferrer, Loren Fidel Ferrer, and Cory G. Ferrer. My family in Germany (Deutschland), particularly: Dr. Jan-Peter Wülbern and his wife Almuth Wülbern. Friends in Chicago and Khambholaj, Natu Patel and the Patel families. 


\section{Notes, Bibliography, Related Links, Etc., Appendix A}

Footnote \#1. A Gängelwagen ('children walker') used by small children in their first steps as seen in this picture https://www.uzh.ch/ds/wiki/ssldir/Textkompetenz/index.php?n=Main.ImmanuelKant

Thanks to Ms. Katie Schaardt of the City archive of Verden for correcting my earlier version and the URL for the picture. Indeed, I find it interesting that Kant is using this image or analogy for Enlightenment in general.

\section{Notes for the text.}

Original publication of Immanuel Kant's essay:

By Immanuel Kant. "Beantwortung der Frage: Was ist Aufklärung?" in Berlinische Monatsschrift Book. 4, 12. (December, 1784), pages 481-494.

Berlinische Monatsschrift. 1783-1811 (full scan text for these years). http://www.ub.uni-bielefeld.de/diglib/aufkl/berlmon/berlmon.htm

Immanuel Kant: AA VIII, AK 8: 33 to AK 8:42. Beantwortung der Frage: Was ist Aufklärung? 1784. Academy Edition of Immanuel Kant (AK). Elektronische Edition der Gesammelten Werke Immanuel Kants. Normal citation format is AK, volume: and page number.

In this case, this essay is Immanuel Kant AK 8:33 to 8:42. From Immanuel Kant's Volume 8, title page, page 33: http://www.korpora.org/Kant/aa08/033.html To Immanuel Kant's Volume 8, last page, page 42: http://www.korpora.org/Kant/aa08/042.html 


\section{Latin phrases used in the text by Immanuel Kant.}

Sapere Aude!

[Latin translated: Dare to Know]

http://en.wikipedia.org/wiki/Sapere aude

From Quintus Horatius Flaccus (born 65 BC - died in 8 BC).

http://en.wikipedia.org/wiki/Horace

natura liter maiorennes

[Latin translated: come of age via nature]

[Latin translated: those who come of age by virtue of nature]

Caesar non est supra Grammaticos

[Latin translated: Caesar is not above the grammarians]

[Latin translated: the emperor is not above the grammerians]

http://en.wikipedia.org/wiki/List_of_Latin_phrases_(C)

\section{German Links:}

Immanuel Kant (1724-1804)

http://de.wikipedia.org/wiki/Immanuel_Kant

Beantwortung der Frage: Was ist Aufklärung?

http://de.wikipedia.org/wiki/Beantwortung_der_Frage:_Was_ist_Aufk1\%C

3\%A4rung\%3F

Moses Mendelssohn (1729-1786)

http://de.wikipedia.org/wiki/Moses_Mendelssohn

Ueber die Frage: was heißt aufklären? By Moses Mendelssohn.

http://de.wikisource.org/wiki/Ueber_die_Frage:_was_hei\%C3\%9Ft_aufkl \%C3\%A4ren\%3F Citation: Berlinische Monatsschrift Bd. 4 (1784), pages 193-200. 
Berlinische Monatsschrift. 1783-1811 (full scan text for these years). http://www.ub.uni-bielefeld.de/diglib/aufkl/berlmon/berlmon.htm

Immanuel Kant's writings in German, AK, volumes 1-23.

Elektronische Edition der Gesammelten Werke Immanuel Kants.

Druckähnliche Darstellung der Bände 1-23.

http://www.korpora.org/Kant/

Deutsches Wörterbuch von Jacob und Wilhelm Grimm. 16 Bde. in 32

Teilbänden. Leipzig 1854-1961. Quellenverzeichnis. Leipzig 1971. OnlineVersion vom 10.08.2013.

"aufklärung, $f$. aufklärung ist die maxime jederzeit selbst zu denken. Kant 1, 136; befreiung vom aberglauben heiszt aufklärung, weil, obschon diese benennung auch der befreiung von vorurtheilen überhaupt zukommt, jener doch vorzugsweise ein vorurtheil genannt zu werden verdient. 7, 153; [Bd. 1, Sp. 675] man spricht viel von aufklärung und wünscht mehr licht. mein gott, was hilft aber alles licht, wenn die leute entweder keine augen haben, oder die, welche sie haben, vorsätzlich verschlieszen. Lichtenberg 1, 201. auch nur aufschlusz, erklärung: kannst du mir aufklärung geben?"

\section{English Links:}

Immanuel Kant (1724-1804)

http://en.wikipedia.org/wiki/Immanuel_Kant

http://plato.stanford.edu/entries/kant/

http://www.rep.routledge.com/article/DB047

http://en.wikipedia.org/wiki/Kantian_ethics

http://plato.stanford.edu/entries/kant-moral/

Answering the Question: What is Enlightenment?

http://en.wikipedia.org/wiki/What_is_Enlightenment\%3F 
Moses Mendelssohn (1729-1786)

http://en.wikipedia.org/wiki/Moses_Mendelssohn

http://plato.stanford.edu/entries/mendelssohn/

Moses Mendelssohn. "On the question: what does "to enlighten" mean?"

Philosophical Writings. By Moses Mendelssohn and Daniel O. Dahlstrom. (Cambridge University Press, 1997), pages 311-317.

Age of Enlightenment

http://en.wikipedia.org/wiki/Age_of_Enlightenment

http://plato.stanford.edu/entries/enlightenment/

\section{Background and Historical Context.}

Steve Naragon of Manchester University gives us these following remarks on the historical and background on the occasion of Immanuel Kant's essay on Enlightenment and he writes:

"Enlightenment "Beantwortung der Frage: Was ist Aufklärung?" in Berlinische Monatsschrift (December 1784), pages 481-94. [AK. 8:3542] "An Answer to the Question: What is Enlightenment?" Translated by Ted Humphrey in Immanuel Kant, Perpetual Peace and Other Essays (Indianapolis: Hackett, 1983), pages 41-46. Translated by Mary J. Gregor in Immanuel Kant, Practical Philosophy, edited by Mary J. Gregor (Cambridge: Cambridge University Press, 1996), pages 17-22.

J. F. Zöllner published an article in the December 1783 issue of the Berlinische Monatsschrift in which he opposed the institution of civil marriage - an idea suggested in an article anonymously written by the journal's editor, J. E. Biester, for the previous September issue and which claimed that tying marriage to religion was contrary to Enlightenment ideals. Zöllner countered that marriage was too important an institution for this and required a stability that only religion could provide. The very 
foundations of morality were being shaken, Zöllner wrote, and we should rethink our steps before "confusing the hearts and minds of the people in the name of Enlightenment" - at which point he asked in a footnote: "What is enlightenment? This question, which is nearly as important as 'What is truth?' should be answered before one begins to enlighten."

Zöllner's question led to a series of essays appearing in the Berlinische Monatsschrift and elsewhere, most famously Kant's (Dec. 1784). An essay by Moses Mendelssohn (“On the Question: What is Enlightenment?") was first delivered as a speech (16 May 1784) before the "Wednesday Society" to which he, Zöllner, Biester, and other leading figures of the Berlin Enlightenment belonged." http://www.manchester.edu/kant/helps/KantsLife.htm\#1780

Steve Naragon of Manchester University gives us these remarks on the historical and background on Immanuel Kant's essay on Enlightenment, and in these specific remarks about the role, that Johann Friedrich Zöllner (1753-1804) played in the overall process and events; and he writes:

"Zöllner also belonged to a secret society in Berlin known as the "Wednesday Society" (Mittwochsgesellschaft), although members referred to the group as "Friends of Enlightenment." It included various high government officials like von Dohm and Klein, philosophers like Moses Mendelssohn, theologians like Spalding, Teller, and Zöllner, as well as the two editors of the Berlinische Monatsschrift (Gedike and Biester ), perhaps the leading journal of enlightenment thought in Germany. Zöllner published an article in the December 1783 issue of that journal in which he opposed the institution of civil marriage - an idea suggested in an article anonymously written by Biester for the September issue and which claimed that tying marriage to religion was contrary to Enlightenment ideals. Zöllner countered that marriage was too important an institution for this, and that it required the stability only religion could provide. The very 
foundations of morality were being shaken, he wrote, and we should rethink our steps before "confusing the hearts and minds of the people in the name of Enlightenment" - at which point he asked in a footnote: "What is enlightenment? This question, which is nearly as important as 'What is truth?' should be answered before one begins to enlighten." This question led to a series of essays appearing in the Berlinische Monatsschrift and elsewhere, most famously Immanuel Kant's "In answer to the question: What is Enlightenment?" (Dec. 1784). Moses Mendelssohn's essay ("On the Question: What is Enlightenment?") was first delivered as a speech (16 May 1784) before the same "Wednesday Society." http://www.manchester.edu/kant/Bio/FullBio/ZollnerJF.html

Berliner Mittwochsgesellschaft (Wednesday Society) http://en.wikipedia.org/wiki/Berliner_Mittwochsgesellschaft Gesellschaft der Freunde der Aufklärung, or Society of Friends of the Enlightenment. Founded in the Fall 1783, and dissolved in Novermber 1798 (by order of Frederick William III of Prussia). There were 24 members. Most of the members published articles in the famous Berlinische Monatsschrift.

James Schmidt wrote: "In addition to serving as co-editor of the Berlinische Monatsschrift, Biester was secretary to Baron Karl Abraham von Zedlitz (Frederick II's minister for ecclesiastical and educational affairs) as well as librarian of the Royal Library in Berlin. "What Counts as an Answer to the Question "What is Enlightenment?". By James Schmidt. http://people.bu.edu/jschmidt/James_Schmidt/Welcome_files/What\%20Co unts.pdf

Manfred Kuehn in his outstanding recent biography of Immanuel Kant remarks: "In December of that same year he published his essay "What Is Enlightenment?" - again in the Berlinische Monatsschrift. Kant dated it September 30,1784. The essay represents a response to a question by Johann Friedrich Zöllner (1748-1805), who was a member of a group of Enlightenment thinkers centered in Berlin. In response to an article in the 
Monatsschrift, whose author had advocated that priests and ministers should no longer play a role in marriage, and that the religious ceremony of marriage contra dicted the spirit of the Enlightenment, Zöllner argued that the principles of morality were already in decline (wankend) and that the disparagement of religion could only accelerate this process. One should not, "in the name of Enlightenment confuse the heads and hearts of the people." In a note in the text, he asked: "What is Enlightenment? This question, which is all most as important as 'What is truth?' should really be answered before one starts to enlighten! And yet, I have not found an answer to it anywhere."

This was the question that Kant meant to answer. He was by no means the only one who addressed this question. A dispute ensued. Kant's answer was the most philosophical, or perhaps better, the most principled one, but it was far from being the only one. He maintained that Enlightenment is humanity's destiny, whereas most of the other papers were concerned with more practical issue." Kant: a biography, (Cambridge University Press, 2001), page 290.

In part of Mary J. Gregor's introduction to her translation in 1996 of Immanuel Kant's essay, she wrote:

"Since the eighteenth century was the "Age of Enlightenment," it was appropriate to ask "What is Enlightenment?" Kant's answer to the question appeared in the December 1784 issue of the Berlinische Monatsschrift. As his concluding note indicates, the September issue, which Kant had not yet received, contained an essay on the same topic by Moses Mendelssohn.

The occasion for both replies to the question could have been an essay in the December 1783 issue,

"Is It Advisable to Sanction Marriage through Religion?" by Johann Friedrich Zöllner, which contained the passage: 
"What is Enlightenment? The question, which is almost as important as the question What is truth?, should be answered before one begins to enlighten others. And yet I have never found it answered anywhere."

As might be expected, Kant's answer and Mendelssohn's were not in agreement. Consistently with his eudaimonism, Mendelssohn had located enlightenment in the cultivation of what Kant would call the theoretical, as distinguished from the practical, use of one's intellectual powers. To this extent, Kant's reply to Garve in "Theory and Practice" would serve against Mendelssohn as well.

Kant's insistence upon freedom of the press, in the present context as the instrument of enlightenment, reappears in virtually all his political writings. A number of points introduced here - Kant's distinction between the public and the private use of reason, his principles of scriptural exegesis, his views about what kind of sect a government could sanction consistently with its own interest - were elaborated in a treatise written in 1794, which had to be withheld from publication because of the repressive measures of Frederick the Great's nephew and successor." (Immanuel Kant, Practical Philosophy, (Cambridge: Cambridge University Press, 1996), page 13).

Johann Friedrich Zöllner (1748-1805). "Ist Es Rathsam, Das Ehebündniß Nicht Ferner Durch Die Religion Zu Sancieren?" Berlinische Monatsschrift II (December, 1783): pages 508-516); and on very last page, page 516 at the bottom of the page, the footnote [*] asked the question: What is Enlightenment? And Immanuel Kant was indeed most likley responding to this question.

See. Berlinische Monatsschrift. 1783-1811 (full scan text for these years). http://www.ub.uni-bielefeld.de/diglib/aufkl/berlmon/berlmon.htm 
James Schmidt's brilliant note on the use of German terminology by Immanuel Kant in this essay.

"Notes 1. The phrase selbstverschuldeten Unmündigkeit is central to Kant's entire argument. As Kant explained in his Anthropology, Unmündigkeit designates both "minority of age" (Minderjährigkeit) and "legal or civil immaturity" (AA VII: 208-209 [Anthropology from a Pragmatic Point of View, trans. Mary J. Gregor (The Hague, 1974), pages 79-80]). Those who are legally immature - a group that includes children, so long as they remain "naturally immature," and women, no matter what age — must be represented in legal proceedings by a "curator" (Kurator), a "proxy" (Stellvertreter), or a "guardian" (Vormund). (All of these designations have their origins in Roman law and were given exhaustive definitions in Christian Wolff's Grundsätze des Naturund Völckerrechts §§898-912.) [1769]. Kant's use of these terms echoes that of Ernst Ferdinand Klein, who in an article on freedom of the press published a few months earlier in the Berlinische Monatsschrift had called on those kings and princes who had taken on the role of Vormüdern over their unmündigen Kinder to follow the example of Frederick the Great and grant them freedom of expression (translated above, pp. 90-91). Enlightened theologians such as Semler and Spalding had also used the term." "What Is Enlightenment?: Eighteenthcentury Answers and Twentieth-century Questions. (The Regents of the University of California), 1996, page, 63. By James Schmidt.

\section{$\underline{\text { Select Bibliography }}$}

Professor Dr. James Schmidt.

http://people.bu.edu/jschmidt/James_Schmidt/Welcome.html

James Schmidt, 2011. "Misunderstanding the Question: 'What is

Enlightenment?': Venturi, Habermas, and Foucault," History of European Ideas 37, no. 1 (2011), pages 43-52. 
Schmidt, James, 2006. "What Enlightenment Was, What it Still Might Be, and Why Kant May Have Been Right After All," American Behavioral Scientist 49:5 (2006), pages 647-663.

Schmidt, James, 1999. "Liberalism and Enlightenment in Eighteenth Century Germany." Critical Review, 13 (1-2), pages 31-53.

Schmidt, James, 1996. What is Enlightenment? Eighteenth-Century Answers and Twentieth-Century Questions, (Berkeley: University of California Press), xii, 563 pages. Many excellent translations from German.

Schmidt, James, 1989. "The Question of Enlightenment: Kant, Mendelssohn, and the Mittwochsgesellschaft." Journal of the History of Ideas, 50(2), pages 269-91.

Michael Clarke (1997). "Kant's Rhetoric of Enlightenment". The Review of Politics, Volume 59, No. 1 (Winter, 1997), pages 53-73

Immanuel Kant: What is Enlightenment? (Summary) - YouTube http://www.youtube.com/watch?v=d3iFie_CrFc

\section{Books by Immanuel Kant with this 1784 essay translated into English}

Chronological Order.

"Answer the Question, What is Enlightening?" By Immanuel Kant. Essays and Treatises on Moral, Political, Religious, and Various Philosophical Subjects. (London: William Richardson: 1798-1799). Volume I., pages A2 to 14. http://archive.org/details/essaysandtreati01kantgoog 
"What is Enlightenment?" On history. By Immanuel Kant. Translation by Lewis White Beck, Robert E. Anchor and Emil L. Fackenheim.

(Indianapolis: Bobbs-Merrill, 1963), pages 3-10.

http://germanhistorydocs.ghi-

dc.org/pdf/eng/12_EnlightPhilos_Doc.2_English.pdf

“An Answer to the Questions: 'What is Enlightenment?". By Immanuel Kant. Translation by H.B. Nisbet. Kant's Political Writings (Cambridge University Press, 1970), pages 54-60.

"An answer to the question, What is enlightenment? (1784)". By Immanuel Kant. Translation by Ted Humphrey. Perpetual peace, and other essays on politics, history, and morals. (Indianapolis: Hackett, 1983), pages 41-46.

"What is Enlightenment? (1784)". Foundations of Ethics. By Immanuel Kant. Translation by Albert Anderson. (Millis MA: Agora Publications $1995,2^{\text {nd }}$ edition 2010), pages 1-6.

“An Answer To the Question: What Is Enlightenment? (1784)". By Immanuel Kant. Translation by By James Schmidt. What Is Enlightenment?: Eighteenth-century Answers and Twentieth-century Questions. By James Schmidt. (The Regents of the University of California, 1996), pages 58-64.

Immanuel Kant, Practical Philosophy, (Cambridge: Cambridge University Press, 1996), pages 17-22. By Immanuel Kant. Translation by Mary J. Gregor. Chapter DOI: http://dx.doi.org/10.1017/CBO9780511813306.005

Mary J. Gregor's translation full text here: http://www.marxists.org/reference/subject/ethics/kant/enlightenment.htm http://www.columbia.edu/acis/ets/CCREAD/etscc/kant.html 
Here is an example of a short note from Immanuel Kant that has at the end a remark about "enlightenment".

“1020. 1773-75? 1775-77? 1776-78? 1778-79? M 251.

$\rho^{2} ? \sigma^{2} ? v^{4} ? \chi^{4} ?$ ? M 251'. [Note: Erich Adickes (1866-1928) uses these for different (33) periods he identified in Kant's hand written notes (Schriftphasen). http://www.manchester.edu/kant/Helps/AdickesSchriftphasen.html Immanuel Kant citation: AK Volume 15: 456

"Everything that is desired or abhorred must be represented (ignoti nulla cupido); but not every representation is the cause of a desire. That in the object which pleases practically as belonging to one's condition or person is desired, either practically or [as] wished. The placens or displicens is the causa impulsiva. People can desire the same thing, but from different motivating causes: honorableness pleases one person because it causes a good reputation, etc. The causa impulsiva is either an impression or a concept, a representation of satisfaction or dissatisfaction through the senses or the understanding, of the agreeable or the good. The first impel per stimulos, the second per motiva. The arbitrium immediate eterminatum per stimulos is brutum. Motiva are either sensitive quoad materiam and immediate and intellectual only quoad formam aut media, but then they are still stimuli, because an action derives its name from its cause and not its manner. The motiva intellectualia pura are what please immediately in the concept; now this is nothing other than a good will, since everything else can only please conditionally as a means (e.g., the works of creation, the talents of human beings) and has the condition that there is a will to make good use of all this. Thus moral goodness alone is absolute goodness, and the motiva moralia are pura. But that which is the universal necessary means for distinguishing motives, namely the enlightenment of practical reason, is also a motivum purum. Hence practical truth." 
[Doch ist das, was daß allgemein nothwendige Mittel ist sie zu unterscheiden: nemlich die Aufklärung der practischen Vernunft, auch ein motivum purum. Mithin practische Warheit.]

Notes and Fragments. By Immanuel Kant. (Cambridge: Cambridge University Press, 2005), pages 407-408. Also in http://books.google.com/

\section{Appendix A.}

First page of Immanuel Kant's

Text of 1784 from the German 


\title{
Berlinifae Monatä̧arift.
}

\author{
1784. \\ 3iwsifses Erü. December.
}

\author{
I. \\ Bcantwortung Der Frage:

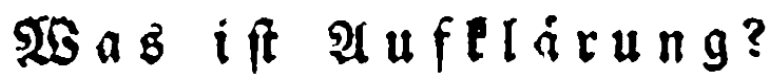 \\ (๑. Deipinb. 1783. S. p16.)
}

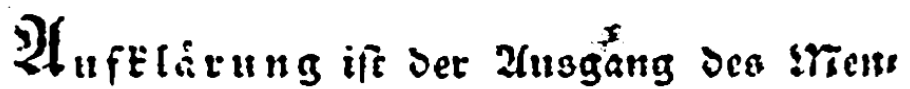

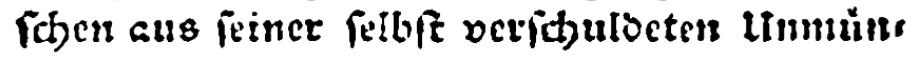
Digfeit. Linmundigfeit if das llnvermigen, (id) leines Berisandes obne Leituna etnes anderen jubeviencn. Gelbfrocejouldet if defe unmün. Digfelt, wiun sie lirfadge Derielben nidhe am Mian:

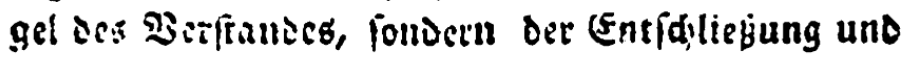
Des Jiutles liegt, fid feiner olue Lettnng eines anoen zu bevienen. Sapere aude! Jabe Mutq Did Deimes eigenen Dee:frandes ju bevicuen! ift als

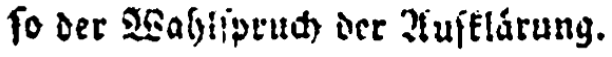

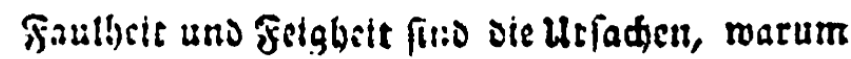
ein io jrolick Shell ver Jjeniden, nachoem fie ble Platur laugfr son frember geitung fref geipredien

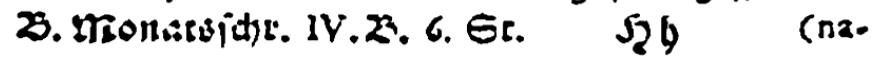

[Caption: this is the first page of Immanuel Kant's article in German and from the original publication of 1784]. 


\section{Index}

\section{A}

AA, 10, 12, 20

aber, 14

aberglauben, 14

abhorred, 23

able, 7

about, 4, 9, 11, 16, 19, 23

above, $7,13,20$

Abraham, 17

absichtlich, 8

absolute, 23

absolutely, 6-7

absurdities, 6

absurdity, 6

Academy, 12

accelerate, 18

accepted, 8

accepting, 5

access, 7

accord, 8

accustomed, 3

acknowledge, 11

Acknowledgements, 11

act, 5, 9

action, 23

actual, 10

actually, 4

addition, 17

addressed, 18

addresses, 4

Adickes, 23 administer, 5

adopted, 6

adore, 9

advances, 4

advantageous, 9

Advisable, 18

advocated, 18

affairs, 9, 17

afraid, 9

After, 21

after, 2-3, 5, 7

afternoon, 11

afterwards, 3

again, 17

against, 6, 19

Age, 15, 18

age, 2, 6-8, 13, 20

Agora, 22

agreeable, 23

agreement, 19

agreements, 6

AK, 10, 12, 14-15, 23

Albert, 22

Alice, 11

All, 10-11, 20-21

all, 3-9, 18-19, 23

Aller, 11

alles, 14

allgemein, 24

allow, 8

allowed, 3-4, 8

allowing, 9

almost, 3, 9, 19

Almuth, 11 
alone, 3-4, 11, 23

already, 9, 18

Also, 24

also, 5, 11, 16, 20, 23

alternate, 4

alternative, 4

although, 16

altogether, 3, 6

always, 3-4

am, 10

Amanda, 11

American, 21

among, 3-4, 6

amongst, 4

amounts, 6

Amts, 5

Amtspflich, 8

An, 15-16, 22

an, 3-7, 10-11, 15-18, 20, 23

analogy, 12

Anchor, 22

And, 18-19

and, 1-12, 15-25

Anderson, 22

angeführt, 10

angelegentliche, 6

anonymously, 15-16

another, 2, 5, 7

Answer, 1, 15, 17, 21-22

answer, 4, 7, 9, 17-19, 22

answered, 9, 16-19

Answering, 14

Answers, 20-22

Anthropology, 20

any, 3, 5, 7-8

anyone, $4,7,10$

anywhere, 18-19

Anzeige, 10

appeared, 18

appearing, 16-17

appears, 9

Appendix, 2, 12, 24

appointed, 5

appreciate, 10

appropriate, 18

arbeiten, 8

arbitrium, 23

archive, 12

are, 2-5, 7-8, 10, 20, 23

argue, 4, 9

argued, 18

argument, 20

arguments, 5 army, 9

article, 15-17, 20, 25

articles, 17

artificial, 4

arts, 8

As, 18-20

as, 2-10, 12, 16-20, 23

Ashlynn, 11

Ashmita, 11

ask, 18

asked, 7, 16-19

assembly, 6

at, 4-9, 16-17, 19, 23

attain, 3

attempt, 3

attempts, 3

Attribution, 10

auch, 14, 24

Aude, 2, 13

audience, 4-5

auf, 6

aufklären, 13

Aufklärung, 1, 8, 12-13, 15, 17, 24

aufklärung, 14

aufschlusz, 14

augen, 14

aus, 8

aut, 23

author, 18

authority, 7

authorized, 6

authors, 3

avaricious, 4

B

back, 9

Background, 15

background, 15-16

Banaras, 11

Baron, 17

BC, 13

Bd, 13-14

Bde, 14

Be, 21

be, 2-9, 16-20, 23

Beantwortung, 1, 10, 12-13, 15

Because, 5 
because, 3, 5, 8-9, 19, 23

Beck, 11, 22

become, 3

Bedrückung, 4

Been, 21

been, 3, 5, 7, 18

before, 4-5, 9, 16-19

befreiung, 14

begins, 16-17, 19

Behavioral, 21

Beherrscher, 8

being, 5, 7, 16-18

beings, 23

believe, 4

believed, 5

belonged, 16

belonging, 23

benennung, 14

Berkeley, 21

Berlin, 16-17

Berliner, 17

Berlinische, 12-20

Berlinischen, 9-10

Bestimmung, 6

Betracht, 8

better, 5-7, 9-10, 18

between, 19

beyond, 8

Bible, 10

Bibliography, 2, 12, 20

Biester, 15-17

bind, 6

biography, 17-18

Bobbs, 22

Book, 12

book, 2

Books, 21

Born, 1

born, 11, 13

both, 18,20

bottom, 19

brilliant, 20

bring, 4, 7, 9

bringen, 10

broken, 10

brought, 3

brutum, 23

burden, 5

business, 5

businesses, 4

But, 3-9, 23

but, 2-5, 7-9, 18, 23

BY, 10
By, 1, 12-13, 15, 17, 20-22, 24

by, 1-8, 12-13, 15-18, 20-22

Bände, 14

Büsching, 9-10
Caesar, 7, 13

California, 20-22

call, 4, 6, 19

called, 4, 20

calling, 4-5

Cambridge, 15, 18-19, 22, 24

can, 2-7, 9-10, 23

cannot, 5-6

capacity, 9

Caption, 25

carefully, 5

carry, 5

cart, 3

case, 12

catechism, 5

Catharina, 11

cattle, 3

causa, 23

cause, 2, 23

causes, 2, 23

Caveats, 10

CCPL, 10

centered, 17

central, 20

Century, 21

century, 8, 18, 20, 22

ceremony, 18

certain, 4,6

certainly, 4

chance, 9

change, 10

changed, 7

Chapter, 22

Chicago, 11

children, 3, 12, 20

Christian, 20

Chronological, 21

Church, 5-6

Citation, 13

citation, 10, 12, 23

citizen, 5-6 
City, 12

city, 11

civil, 4, 7, 9, 15-16, 20

claimed, 15-16

Clarke, 21

classis, 6

clean, 6

clear, 8

clergy, 6, 8

clergyman, 4-6

closed, 6

closer, 10

co, 17

collector, 4

come, 2, 4, 9, 13

command, 5

commanded, 5

Commercial, 10

commit, 6

Commons, 10

communicated, 5

community, 4-5, 8

complete, 5,8

concept, 23

concern, 7

concerned, 18

concerning, 9

concluding, 18

condition, 5-6, 23

conditionally, 23

conducive, 9

conduct, 4

confirmed, 6

confuse, 18

confusing, 16-17

congregation, 5

congregations, 7

connected, 5

conscience, 2, 5, 8

considered, 8

Consistently, 19

consistently, 19

conspire, 6

constant, 6

constitution, 7

constrained, 5

contained, 18

Contents, 2

Context, 15

context, 19

continuous, 6

contra, 18

contract, 6 contradictory, 5

contrary, 5, 15-16

contrast, 5, 9

convenient, 2

conversational, 10

conversations, 11

conviction, 5

copyright, 10

correcting, 12

Cory, 11

could, 5-7, 9, 15-16, 18-19

countered, 15-16

Counts, 17

courage, 2

course, 10-11

cowardice, 2

crash, 7

creation, 23

Creative, 10

creatures, 3

crime, 6

Critical, 21

criticism, 5, 9

cultivation, 19

cupido, 23

curator, 20

current, 9

Curtis, 11

D

da, 10

Dahlstrom, 15

danger, 3, 9

dangerous, 3

Daniel, 1, 10-11, 15

Dare, 2, 13

dare, 3, 9

darin, 8

Darstellung, 14

Das, 19

das, 8,24

dated, 17

daß, 6, 24

deal, 7

Dec, 16-17

December, 12, 15-19

decides, 2 
decline, 18

decree, 7

Dedication, 11

definitions, 20

degrading, 8

degree, 9

deliberately, 8

delivered, 16-17

delivery, 7

demonstrate, 7

den, 10

denken, 14

Denn, 6

Department, 11

der, 1, 6, 8, 10-15, 17, 24

derives, 23

derselben, 10

des, 6, 10, 20

deserves, 8

designates, 20

designations, 20

desirability, 5

desire, 23

desired, 23

despotism, 4, 7

dess, 10

destiny, 18

destroy, 7

destruction, 4

determination, 6

Deutsches, 14

Deutschland, 11

devised, 5

dicted, 18

did, 10

Die, 8, 19

die, 6, 10, 13-14, 24

died, 1, 11, 13

diese, 14

diesem, 8, 10

dieses, 8

diet, 2

different, 8, 23

difficult, 2-3

dignity, 9

Dingen, 6

direction, 2, 7

disadvantage, 7

disastrous, 5

discard, 6

disciplined, 9

disparagement, 18

displicens, 23 dispute, 18

dissatisfaction, 23

dissolved, 17

distinction, 19

distinguished, 19

distinguishing, 23

distribution, 10

do, 2-5, 7, 10

Doch, 24

doch, 14

does, 5, 7-10, 15

Dohm, 16

DOI, 22

doing, 7

Dolores, 11

domestic, 3

done, 11

doubting, 7

Dr, 11, 20

drill, 4

Druckähnliche, 14

du, 14

Durch, 19

Dutch, 6

duties, 5, 8

duty, 5, 8

E

each, 6, 8

earlier, 12, 20

earnestly, 6

easy, 2, 10

eben, 10

ecclesiastical, 17

echoes, 20

edited, 15

Edition, 12, 14

edition, 22

editor, 15,17

editors, 16

educational, 17

Ehebündniß, 19

Eighteenth, 21-22

eighteenth, 18

Eighteenthcentury, 20

Ein, 8

ein, 14, 24 
eine, 6

Einschränkung, 4

Einstimmigkeit, 10

either, 23

elaborated, 19

Elektronische, 12, 14

else, 5, 23

elsewhere, 9, 16-17

emergence, 2

Emil, 22

emperor, 13

enabled, 9

encountered, 5

encouragement, 11

END, 10

end, 23

English, 1-2, 14, 21

enjoys, 6

enlighten, 3, 15-19

Enlightened, 20

enlightened, 7-9

Enlightening, 21

Enlightenment, 1-4, 6-8, 12, 14-22

enlightenment, 16-17, 19, 22-23

ensued, 18

entire, 2, 4, 7, 20

entirely, 5

entrusted, 4

entschlug, 8

entweder, 14

erhalten, 8

Erich, 23

erklärung, 14

Ernesto, 11

Ernst, 20

erroneous, 6

error, 5

errors, 6, 11

Es, 19

escape, 8

Especially, 3

especially, 6, 8

essay, 9, 12, 15-18, 20-21

Essays, 15, 21

essays, 16-17, 22

est, 7, 13

established, 3

establishment, 5

estimate, 3

Etc, 2, 12

etc, 2, 23

eterminatum, 23

Ethics, 22 eudaimonism, 19

European, 20

evaluate, 7

even, 2-3, 5-10

event, 5

events, 16

everlasting, 3

every, 3, 6, 23

Everything, 23

everything, 9, 23

everywhere, 4

example, 3, 8-9, 20, 23

excellent, 21

excessively, 10

exegesis, 19

exercise, 3,9

exhaustive, 20

expand, 9

expectation, 6

expected, 19

expediency, 4

explain, 8

explained, 20

expresses, 5

expression, 20

extent, 6, 19

external, 2, 8

extracts, 5

extricate, 3
Fackenheim, 22

fact, 5-7

fair, 2

Fall, 17

falling, 3

families, 11

family, 11

famous, 10, 17

famously, 16-17

far, 2, 6-7, 9, 18

faulty, 5

favors, 8

feel, 10

Ferdinand, 20

Ferner, 19

Ferrer, 1, 10-11 
fetters, 3

few, 3, 20

Fidel, 1, 10-11

field, 7

figures, 16

Finally, 9

finally, 3

find, 12

finds, 8

First, 24

first, 3, 8, 12, 16-17, 23, 25

fit, 5

Flaccus, 13

follow, 20

followed, 10

following, 6, 15

fond, 3

fondly, 9

Footnote, 12

footnote, 3, 9-10, 16-17, 19

For, 3-5

for, 2-10, 12, 14-19, 23

forces, 3

forehand, 3

forever, 6

formam, 23

format, 12

formulas, 3

formulations, 9

fortune, 7

forward, 5

Foucault, 20

found, 3, 5, 18-19

Foundations, 22

foundations, 16-17

Founded, 17

Frage, 1, 10, 12-13, 15

Fragments, 24

frank, 9

Frederick, 8, 17, 19-20

Free, 10

free, 3-5, 8-9

freedom, 3-6, 8-9, 19-20

freely, 6, 8

Freistaat, 9

Freunde, 17

Friederichs, 8

Friedrich, 16-19

friend, 11

Friends, 11, 16-17

frightens, 3

From, 12-13

from, 2-5, 7-8, 18-21, 23-25 fruitless, 7

full, 12, 14, 19, 22

fully, 6, 9

further, 3, 6, 8

Fürst, 8

Füßen, 7

G

ganze, 2

Ganzen, 7

Garve, 19

geben, 14

Gebrauche, 4

Gedanken, 10

gedankenlosen, 4

Gedike, 16

gegenwärtige, 10

gehorcht, 4

Geistes, 3

Geistliche, 8

geistlichen, 6

gekommen, 10

gemeinen, 8

genannt, 14

General, 10

general, 5, 7, 11-12

generally, 10

germ, 9

German, 4-5, 9-10, 13-14, 20-21, 24-25

Germany, 11, 16, 21

Gesammelten, 12, 14

Geschäfte, 4

Gesellschaft, 17

get, 7

Gewissen, 2

gifts, 3

given, 5, 9, 20

gives, 9, 15-16

go, 3

goes, 8

good, 7, 23

goodness, 23

gott, 14

governance, 7

government, 4, 8-9, 16, 19

graciously, 3

gradually, 8-9 
graduate, 11

grammarians, 7, 13

Grammaticos, 7, 13

grammerians, 13

Grand, 11

grant, 20

grateful, 8

Great, 19-20

great, 3-4

greater, 9

green, 10

Gregor, 15, 18, 20, 22

Grimm, 14

group, 16-17, 20

grown, 3

großen, 4

Grundsätze, 20

guarantee, 9

guardian, 8, 20

guardians, 2-3, 6

guardianship, 6

guidance, 2

Gängelwagen, 3, 12

H

haben, 10, 14

Habermas, 20

Hackett, 15, 22

had, 5-7, 18-20

Hague, 20

hand, 9, 23

hard, 9

harmful, 3, 8

harmless, 4

harness, 3-4

Harvey, 11

has, 2-3, 5, 9, 23

Haufens, 4

haughty, 8

Hauptpunkt, 8

Have, 2, 21

have, 2-3, 5-11, 18-20

He, 3, 5, 7, 18

he, $3-5,7-8,11,15-18,23$

head, 8

heads, 18

hear, 4 hearts, 16-18

heiszt, 14

heißt, 13

held, 4, 9

help, 10

Hence, 23

her, 18

heraus, 8

Here, 4, 23

here, 8-9, 19, 22

herein, 3

Herrn, 9-10

herrschsüchtiger, 4

heute, 10

hidden, 5

high, 16

highest, 7

hilft, 14

hillside, 9

him, 3-4, 7-8

himself, 3, 5, 7-9

hinausläuft, 6

hindering, 4

Hindernisse, 7

hinders, 4

Hindu, 11

hired, 5

His, 11

his, 2-11, 17-20

Historical, 15

historical, 15-16

History, 20-21

history, 22

Holger, 11

home, 5

honorableness, 23

Horace, 2

Horatius, 13

how, 9

However, 5-6

however, 4-5, 9

human, 6-9, 23

humanity, 2, 18

humbled, 7

Humphrey, 15, 22

Händen, 10 
ich, 10

idea, 15-16

ideals, $15-16$

Ideas, 20-21

identified, 23

If, 4, 6-7, 9-10

if, $2-3,5-6,8$

ignore, 10

ignoti, 23

II, 17,19

III, 17

illuminated, 8

image, 12

Immanuel, 1-2, 10-25

immature, 2, 6, 20

Immaturity, 2

immaturity, 2-3, 8, 20

immediate, 23

immediately, 23

impel, 23

impertinent, 5

important, 15-19

imposed, 2, 5-6, 8

impossible, 5-6

impression, 23

impropriety, 5

improvement, 7

impulsiva, 23

In, 5, 8, 10, 12, 17-18

in, $1-21,23-25$

inability, 2

incapable, 3

incited, 3

included, 16

includes, 20

including, 2, 11

incurred, 2

Indeed, 10, 12

indeed, 5, 19

independent, 3

Index, 2

Indianapolis, 15, 22

indicates, 18

indications, 8

individual, 3

inescapable, 9

injustice, 5

inner, 5

insight, 6-7

insights, 7-8

insistence, 19

instead, 4

institution, 6, 15-16

instrument, 19

insubordination, 5

intellectual, 19, 23

intellectualia, 23

intention, 6

intentioned, 5

interest, 4, 8, 19

interesting, 12

interfering, 7

interpretation, 10

into, 1-2, 6-8, 10, 21

introduce, 6

introduced, 6, 19

introduction, 18

irksome, 2

Is, 4, 17-18, 20, 22

is, $1-10,12-23,25$

issue, 15-16, 18

Ist, 19

ist, 1, 6, 8, 10, 12-15, 24

It, 2, 4, 7, 9, 16, 18

it, 2-10, 12, 16-19, 21, 23

its, 2, 6, 8-9, 19, 23

itself, 3-4, 6, 9

Jacob, 14

Jahrhundert, 8

James, 17, 20-22

Jan, 11

jederzeit, 14

jener, 14

jetzt, 10

Jo, 11

Johann, 16-19

Joseph, 11

Journal, 21

journal, 15-16

Juanita, 11

judgments, 8

Julius, 11

just, 4,9 
justified, 6

Justine, 11

justly, 5

Kaiden, 11

kannst, 14

Kant, 1-2, 9-25

Kants, 12, 14

Karl, 17

Katie, 12

keep, 8

keine, 14

Khambholaj, 11

kind, 3, 10, 19

Kinder, 20

kings, 20

Kiran, 11

Klein, 16, 20

Know, 13

know, 2, 7, 10

knowledge, 6

known, 16

Kontrakt, 6

Kuehn, 17

Kuhn, 11

Kurator, 20

Königsberg, 1, 9

könne, 10

künstelt, 8

L

lack, 2

land, 8

language, 10

Large, 11

large, 2, 5, 9

largest, 2

Last, 10

last, 6, 12, 19

Latin, 2, 7, 13

Laurie, 11 law, 6, 20

lays, 7

Laziness, 2

lead, 6

leading, 16

leap, 3

learn, 3, 10

learning, 10

least, 4-5, 8

leave, 7

led, 16-17

legal, 7, 20

legally, 20

legislation, 9

Leipzig, 14

lese, 10

less, 7-8

lesser, 9

lest, 7

let, 3, 6

letter, 10

leute, 14

levies, 5

Lewis, 11, 22

Liberalism, 21

liberty, 8

librarian, 17

Library, 17

License, 10

licht, 14

Lichtenberg, 14

lies, 2, 5-6

life, 2

lifetime, 7

like, 2-3, 10-11, 16

likley, 19

limitations, 9

Links, 2, 12-14

liter, 2, 13

literate, 4

little, 8

living, 7

located, 19

London, 21

long, 10, 20

longer, 18

longtime, 11

look, 9

Loren, 11

lot, 7

Louise, 11

lunch, 11

Luther, 10 


\section{M}

MA, 22

machine, 4,9

made, 3

mag, 10

mails, 11

main, 8

mainly, 6

maintained, 18

maiorennes, 2, 13

majesty, 7

make, 3-4, 6-7, 23

makes, 3-5, 9

making, 5

malicious, 6

Maliha, 11

man, 2-3, 7-9, 14

Manchester, 15-16

Manfred, 17

mankind, 7

manner, 6, 23

Many, 21

many, 10-11

Marguerita, 11

Marriage, 18

marriage, 15-16, 18

Martin, 10

Mary, 15, 18, 20, 22

Maschine, 4

mass, 4

masses, 3

materiam, 23

matter, 20

matters, 6-8

maturity, 2

maxime, 14

May, 16-17, 21

may, $4,7,9$

me, 2,9

mean, 15

means, $4,6,18,23$

meant, 18

measures, 19

mechanical, 3

mechanism, 4

media, 23

meeting, 5

mehr, 14

mein, 14 member, 4,17

members, 4, 6, 11, 16-17

men, 3-4, 8

Mendelssohn, 9-10, 13, 15-19, 21

Menschen, 8

merely, 5

Merrill, 22

Michael, 21

Michigan, 11

Might, 21

might, 6, 19

military, 5

Millis, 22

mind, 2-3

Minderjährigkeit, 20

minds, 16-17

mine, $10-11$

minister, 17

ministers, 18

minority, 20

Mir, 10

mir, 14

missing, 7

Misunderstanding, 20

misunderstanding, 8

misuse, 3

Mithin, 24

Mittel, 24

Mittwochsgesellschaft, 16-17, 21

mixes, 7

monarch, 7, 9

Monat, 10

Monatsschrift, 10, 12-20

Monthly, 9

months, 20

Moral, 21

moral, 23

moralia, 23

morality, 16-18

morals, 22

more, 3, 7-9, 18

moreover, 8

Moses, 13, 15-18

Most, 17

most, 4, 6, 8-10, 16-19

mother, 11

Motiva, 23

motiva, 23

motivating, 23

motives, 23

motivum, 23-24

motto, 2

movement, 3 
Ms, 12

much, 8

must, 4-6, 20, 23

My, 10-11

my, 2, 10-12
Notes, 2, 12, 20, 24

notes, 5,23

nothing, 4-5, 8, 23

nothwendige, 24

notwithstanding, 5

Novermber, 17

Now, 3, 6

now, 4, 7, 9, 23

null, 6

nulla, 23

number, 12,19

numerous, 9

nur, 8, 10, 14

nach, 8

Nachkommenschaft, 7

Nachrichten, 9-10

name, 5, 8, 16-18, 23

namely, 4, 9, 23

Naragon, 15-16

narrowest, 3

narrowly, 4

native, 10

Natu, 11

natura, 2, 13

natural, 3

naturally, 20

nature, 2-3, 6, 9, 13

Naturund, 20

NC, 10

nd, 22

nearly, 16-17

necessary, 4, 7, 23

need, 2

Nein, 7

nemlich, 24

nephew, 19

never, 3-4, 19

new, 4

newly, 6

news, 9

Nicht, 19

nicht, 8, 10

Nisbet, 22

No, 7, 21

no, 8-9, 18, 20

noch, 10

Non, 10

non, 7, 13

nonetheless, 5

Normal, 12

not, 2-10, 13, 18-19, 23

Note, 23

note, 4-5, 9, 18, 20, 23

oath, 6

Oberaufsicht, 3

obey, 4-5, 9

object, 23

obschon, 14

obstacles, 7-8

occasion, 5, 15, 18

oder, 8,14

Of, 10

of, $2-13,15-25$

off, 3,6

office, 4-5

officer, 4-5

official, 8

officials, 16

offspring, 6

often, 4

old, 4, 10

On, 15-17, 22

on, $3,5-7,11,15-16,18-22$

Once, 3

One, 6, 18

one, 2-6, 8-9, 16-19, 23

ones, 4

OnlineVersion, 14

Only, 4

only, 2-3, 5, 7-10, 15-16, 18, 23

opened, 7

operate, 8

opinion, 5

opposed, 15-16

oppression, 4 
or, $3-10,12,17-18,20,23$

Order, 21

order, 4, 6-7, 17

organization, 7

Original, 12

original, 6,25

origins, 20

Other, 15

other, 7-8, 10, 16, 18, 22-23

others, 2,19

otherwise, 9

our, 5, 8-9, 11, 16-17

out, 3

outstanding, 17

over, 6-8, 10, 20

overall, 11,16

own, 2-3, 6-9, 19

\section{$\mathbf{P}$}

pace, 3

page, 10, 12, 18-20, 24-25

pages, 2, 12-13, 15, 19-22, 24

paid, 5

papers, 18

paradoxical, 9

paragraphs, 10

parliaments, 6

part, 2, 4, 8, 18

particularly, 4, 11

passage, 18

passive, 4

passively, 4

pastor, 2

pastors, 6

Patel, 11

path, 9

pay, 2, 4-5

pdf, 17

Peace, 15

peace, 6, 8-9, 22

People, 8, 23

people, 2, 6-7, 9, 16-18

per, 23

perceived, 7

perhaps, 4, 6, 16, 18

period, 6-7

periods, 23
Perpetual, 15, 22

perpetuate, 6

perpetuation, 6

persistent, 7

person, 5-7, 23

personal, 4

Peter, 11

philologist, 10

philosophers, 16

Philosophical, 15, 21

philosophical, 11, 18

Philosophy, 11, 15, 19, 22

philosophy, 11

phrase, 20

phrases, 13

physician, 2

picture, 12

placens, 23

places, 9

placid, 3

plant, 3

play, 18

played, 16

playing, 8

please, 23

pleases, 23

Point, 20

point, 8, 16-17

points, 19

Political, 21-22

political, 19

Politics, 21

politics, 22

possible, 3,6

post, 4

posterity, 7-8

postpone, 7

power, 6

powers, 19

pp, 20

Practical, 15, 19, 22

practical, 5, 18-19, 23

practically, 23

Practice, 19

practische, 24

practischen, 24

Pragmatic, 20

praised, 8

precepts, 5

precisely, 6

predecessors, 3

prejudice, 4

prejudices, 3-4 
prescribe, 8

present, 6, 19

presentation, 5

presents, 5

Press, 15, 18-19, 21-22, 24

press, 19-20

prevent, 7

prevented, 7

previous, 15

previously, 3

priest, 5

priests, 18

prince, 8

princes, 20

principled, 18

principles, 9, 18-19

Private, 4

private, 4-5, 19

Privatgebrauch, 4

probably, 4, 7

proceedings, 20

process, 16, 18

procure, 8

professional, 10

Professor, 11, 20

progeny, 7

progress, 4, 6-7

project, 11

proper, 4

proportion, 2

proposal, 6

proposed, 8

protection, 7

provide, 9, 15-16

provision, 5,7

proxy, 20

Prussia, 1, 9, 17

Public, 10

public, 3-6, 8-9, 19

publication, 12, 19, 25

Publications, 22

publicly, 5-8

published, 15-17, 20

Pulaski, 11

punctuation, 10

punished, 5

pura, 23

pure, 7

purpose, 11

purposes, 4

purum, 23-24

put, 5-6 quality, 4, 6, 8

Quellenverzeichnis, 14

Question, 14-17, 20-22

question, 1, 6, 9, 15-19, 22

questioner, 11

Questions, 20-22

Quintus, 13

quoad, 23

$\mathbf{R}$

race, 6,8

Rafael, 11

Rai, 11

Rapids, 11

rather, 2-5, 7-8

Rathsam, 19

rational, 3

re, 10

read, 9

reader, 10

readily, 2

reading, 10

real, 7

really, 3,18

reappears, 19

reason, 4-6, 8-9, 19, 23

reasonable, 3

Reavis, 11

received, 18

recent, 11,17

Recently, 11

recommend, 10

reduced, 7

referred, 16

reform, 4

refuse, 5

regard, 8

regardless, 8

regards, 4

Regents, 20, 22

Regierung, 9

regime, 9

rejecting, 6 
Related, 2, 12

release, 8

released, 2

Religion, 18-19

religion, 5, 7-8, 15-16, 18

Religious, 21

religious, 7-8, 18

remain, 2-3, 20

remark, 23

remarks, $6,10,15-17$

ren, 13

rendered, 3

renounce, 7

renouncing, 8

replies, 18

reply, 19

representation, 23

represented, 20, 23

represents, 17

repressive, 19

reproach, 7

reputation, 23

required, 4, 15-16

reserved, 10

resign, 5

resists, 5

resolve, 2

respect, 5, 8

responding, 19

response, 17

responsible, 4

restricted, 4, 8

restriction, 4

rests, 7

result, 5

rethink, 16-17

return, 9

revenge, 3

Review, 21

revise, 10

revolution, 4

rewritten, 10

Rhetoric, 21

Richard, 11

Richardson, 21

Right, 21

rights, 7, 10

ripe, 10

Rita, 11

Robert, 22

Roheit, 8

role, 16, 18, 20

Roman, 20 room, 9

Royal, 17

rudness, 8

Ruhe, 8

ruler, 4

rulers, 8

run, 4

rung, 13

Ruth, 11

sacred, 7

sake, 7

salvation, 7

same, 4-5, 7, 9, 17-18, 23

Sancieren, 19

Sanction, 18

sanction, 19

Sapere, 2, 13

satisfaction, 23

say, 5-6, 9

says, 4,6

scan, 12, 14, 19

scandal, 5

Schaardt, 12

schen, 10

Schmidt, 17, 20-22

scholar, 4-6

scholars, 8

school, 11

Schriftphasen, 23

sciences, 8

Scientist, 21

Scott, 11

scriptural, 19

second, 23

secret, 16

secretary, 17

sect, 19

secure, 6-7

See, 19

see, 4

seek, 7

seems, 9

seen, 12

sees, 5, 7-8

sein, 6 
seines, 5

selbst, 6, 8, 14

Selbstdenkende, 3

selbstverschuldeten, 2, 20

Select, 20

Self, 2

self, 2,8

Semler, 20

sense, 4

senses, 23

sensitive, 23

sentences, 10

Sept, 10

September, 1, 9-10, 15-18

series, 16-17

serve, 4, 19

serves, 5

service, 5

serving, 5, 17

set, 2,8

sex, 2

sexual, 8

shadows, 9

shaken, 16-17

shall, 4

she, 18

shell, 9

shining, 9

Shobha, 11

short, 6, 23

should, 3, 5-6, 16-19

shows, 3

shut, 6

sich, 8

sides, 4

sie, $8,10,14,24$

Similarly, 5

Since, 18

since, 5, 7, 23

single, 3

Sinnesart, 9

slowly, 3

small, 12

So, 3-4

so, 2-3, 6, 8-9, 20

Society, 16-17

society, 4, 6, 16

solemn, 6

sollen, 6

some, 3-4, 6-7, 10

someone, 5

something, 5

sonst, 10
Sp, 14

Spalding, 16, 20

speak, 6

speaker, 10

specific, 6, 16

speech, 16-17

spirit, 3, 8, 18

spiritual, 6-7

spread, 3

spreads, 8

spricht, 14

stability, 15-16

stand, 7

Start, 2

starts, 18

state, 7-9

stated, 9

Statutes, 3

steady, 3

stehen, 10

Stellvertreter, 20

sten, 10

step, 2-3

steps, 3, 12, 16-17

Steve, 15-16

Still, 21

still, 3, 7, 23

stimuli, 23

stimulos, 23

strange, 9

struggling, 8

students, 5

stupid, 3

Subjects, 21

subjects, 7-9

submit, 5

subscribe, 5

succeeded, 3

successor, 19

Such, 6

such, 2, 5-6, 20

suffering, 4

suggested, 15-16

suggestions, 5

Summary, 21

superior, 5

supervisor, 3

support, 7

supra, 7, 13

supreme, 6-7

sure, 3

surpasses, 9

Symbol, 5 
symbol, 5-6, 8-9

Table, 2

take, 3, 6-7

taken, 20

talents, 23

tax, 4

taxes, 5

teach, 5,10

teacher, 5

teaches, 5

Ted, 15, 22

Teilbänden, 14

Teller, 16

temperament, 9

tenders, 5

term, 20

terminology, 20

terms, 7, 20

tested, 5

testing, 8-9

TEXT, 10

Text, 2, 24

text, 10, 12-14, 18-19, 22

than, 8-10, 23

Thanks, 12

That, 2, 6-7, 23

that, 2-9, 12, 15-18, 20, 23

The, 4-5, 7, 15-23

the, $1-25$

their, 2-3, 5-9, 12, 20

them, 2-3, 5, 8-9, 20

themselves, 2-4, 6-7

Then, 7

then, 7, 23

theologians, 16, 20

theoretical, 19

Theory, 19

There, 5, 17

there, 3, 7-9, 23

Therefore, 3

therefore, 5, 10

these, 3-7, 12, 14-16, 19-20, 23

they, 3, 5-8, 10, 20, 23

thing, 23

things, 7 think, 2-3

thinkers, 3, 17

thinking, 4, 8-9

This, 7-8, 10, 16-18

this, $2-12,15-16,18-21,23,25$

Those, 20

those, 3, 6-8, 13, 20

though, 6

thought, 9, 16

thoughts, 5, 9

threatens, 3

throne, 7

through, 5-6, 18, 23

throwing, 3

thrown, 3

throws, 3

Thus, 2-3, 23

thus, 4-5, 7

time, 4, 7, 9

times, 3

timid, 3

title, 12

To, 9, 11-12, 19, 22

to, 2-13, 15-23

today, 9

tolerance, 8

too, 15-16

took, 3

tools, 3

topic, 18

touchstone, 6

toward, 7

trampled, 7

trans, 20

transition, 9

Translated, 15

translated, 2, 7, 13, 20-21

Translation, 1, 10, 22

translation, 10-11, 18, 22

translations, 10, 21

Translator, 4-5, 9-10

translator, 10

treat, 9

treaties, 6

treatise, 19

Treatises, 21

trench, 3

tried, 6

true, 4

truth, 5, 16-19, 23

try, 2-3

tutelage, 2

Twentieth, 20-22 
two, 16

tying, 15-16

tyrannical, 4

tyrants, 7 uses, 5, 9, 23

using, 7, 12

usually, 3

utility, 5
Ueber, 13

ultimate, 3

um, 8

unalterable, 6

unanimity, 4, 9

unauthorized, 6-7

uncertain, 3

und, 8,14

Under, 8

under, 3, 7

underfoot, 7

understand, 4, 10

understanding, 2-3, 7, 23

understands, 2

undertake, 2, 5

unexpected, 9

Ungereimtheit, 6

Ungereimtheiten, 6

united, 7

unites, 7

uniting, 6

unity, 8

universal, 23

University, 11, 15-16, 18-22, 24

unlimited, 6, 10

unmündig, 6

unmündigen, 20

Unmündigkeit, 2-3, 20

unterscheiden, 24

unthinking, 4

until, 6

unts, 17

unworthy, 8

unwrapped, 9

up, 2, 10

upon, 3, 7, 19

URL, 12

Ursachen, 2

us, 15-16

use, 2-7, 9, 19-20, 23

used, 12-13, 20
Vandana, 11

Various, 21

various, 16

venerable, 6,8

venerate, 9

Venturi, 20

Verden, 11-12

verdient, 14

verehren, 9

Verewigung, 6

Vernunft, 4, 24

Versandes, 2

verschlieszen, 14

verschwören, 6

version, 10, 12

Verstandes, 3

Versuche, 10

very, 3-5, 7, 15-16, 19

via, 2,13

viel, 14

View, 20

views, 19

VII, 20

VIII, 10, 12

violate, 7

violence, 5

violent, 7

virtually, 19

virtue, 13

vocation, 3

Vogelsang, 11

voices, 6

void, 6

Volks, 6

Volkswillen, 7

Volume, 12, 21, 23

volume, 12

volumes, 14

vom, 10, 14

von, 8, 10, 14, 16-17

Vormund, 20 
Vormüdern, 20

Vormünder, 3, 6

vorsätzlich, 14

vorurtheil, 14

vorurtheilen, 14

vorzugsweise, 14

Völckerrechts, 20

W

walk, 3, 11

walker, 12

walking, 3

wankend, 18

want, 4, 9

wanted, 7

Warheit, 24

Was, 1, 12-13, 15, 21

was, 5, 8, 13-19, 24

waste, 4

way, 7-8

ways, 4

we, 7-9, 16-17

Wednesday, 16-17

weekly, 9

weil, 14

weiterzuschreiten, 6

welche, 14

well, 3-5, 7, 9-10, 16-17, 19

wenn, 8, 14

went, 11

werden, 14

were, 3, 16-20

Werke, 12, 14

Wesens, 8

What, 1, 14-22

what, 4-5, 7, 9, 15, 19-20, 23

When, 7

when, 2-3, 5, 7, 9

where, 7-8, 11

whereas, 18

wherein, 9

Whether, 6

which, 2-9, 15-19, 23

while, 8

White, 11, 22

who, 2-5, 7-10, 13, 17-18, 20

Whoever, 3 whole, 4, 7

whom, 9

whose, 5-6, 18

Why, 21

why, 2

wieder, 6

wiefern, 10

wife, 11

Wilhelm, 14

will, 2-3, 5, 7, 23

William, 17, 21

Williams, 11

Winter, 21

wird, 10

wished, 23

with, 5-7, 9, 11, 18-19, 21

withheld, 19

within, 7

without, 2-4, 7

Wolff, 20

women, 20

Word, 2

word, 4-5, 9-10

words, 10

worin, 10

work, 2-3, 7-9

works, 23

world, 4, 6, 8-9

worship, 9

worth, 3

would, 3, 5-7, 9, 11, 19

write, 10

writes, 15-16

writing, 6

Writings, 15, 22

writings, 6-7, 14, 19

written, 10, 15-16, 19, 23

wrote, 10, 16-18

wöchentliche, 9

wöchentlichen, 10

Wörterbuch, 14

Wülbern, 11

wünscht, 14

würde, 10

$\mathbf{X}$

xii, 21 


\section{Y}

year, 17

years, 10, 12, 14, 19

yes, 3

yet, 9, 18-19

yoke, 3

you, 3-4, 9

Young, 11

your, 2

YouTube, 21

\section{$\mathbf{Z}$}

Zaborowski, 11

Zedlitz, 17

Zeitalter, 6, 8

Zoe, 11

$\mathrm{Zu}, 19$

zu, 8, 10, 14, 24

Zufall, 10

zukommt, 14

zum, 10

zurückgehalten, 10

zuwege, 10

Zöllner, 15-19

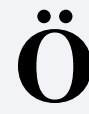

öffentliche, 8

öffentlichen, 4

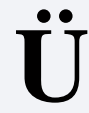

überhaupt, 14 